\title{
The Role Model Effect of Sports Celebrites in Social Media on the Behavioral Intentions of Generation $\mathrm{Z}^{1}$
}

\author{
DOI: $10.26466 /$ opus. 876057 \\ * \\ Mehmet Mürütsoy * - Murat Toksar1 ** \\ * Dr., Niğde Ömer Halisdemir Üniversitesi, Niğde/Türkiye \\ E-Posta: m.muritsoy@gmail.com \\ ORCID: 0000-0002-0942-3814 \\ ** Doç.Dr., Sivas Cumhuriyet Üniversitesi, İletişim Fakültesi, Sivas/Türkiye \\ E-Posta: mtoksari@cumhuriyet.edu.tr \\ ORCID: $\underline{0000-0001-9021-2274}$
}

\begin{abstract}
The aim of this study is to show the role model effect of sports celebrities in social media on Gen Z's brand loyalty, switching and complaining behavior and positive electronic word-of-mouth behavior (positive EWOM). The use of sports celebrities in advertising is of great interest to many businesses and organizations. When the literature is analyzed, although there are many studies on the use of sports celebrities in traditional media ads, it's seen that there are very few studies on the use of sports celebrities in social media ads. In recent years, social media has become a new and popular online marketing channel. Especially, the increase in the number of consumers using social media sites day by day has made social media an important means of advertising. On the other hand it is really important for marketers to benefit from the support of role models, since the role models are important figures that influence the consumers' behaviours. This study was conducted with 223 people from ages 18-22 in Nigde, Turkey. Structural equation model is used for the analysis of the data obtained from 223 participants. As a result it is found out that there is a positive relationship between role model effect of sports celebrities and brand loyalty along with positive EWOM behavior.
\end{abstract}

Keywords: $\quad$ Social Media, Sports Celebrities, Generation Z, Role Model Effect

\footnotetext{
${ }^{1}$ This article has been produced by using a part of the data obtained from the doctoral dissertation titled "The Effect of Sports Celebrities Use in Social Media Advertisements on The Purchasing Behavior of Consumers: A research on The $X, Y$ and $Z$ Generation in Nigde Province.," which was written by the first author and supervised by the second author.
} 


\section{Sosyal Medya Üzerindeki Ünlü Sporcuların Z Kuşağının Davranışsal Niyetleri Üzerindeki Rol Model Etkisi}

Öz

$B u$ çalışmanın amacı sosyal medya üzerindeki ünlü sporcuların $\mathrm{Z}$ kuşağındaki tüketicilerin marka sadakati, firma tercihi değişikliği ve şikayet davranışı ve pozitif elektronik ă̆ızdan ă̆za pazarlama davranışı (pozitif EWOM) üzerindeki rol model etkisini ortaya çıkarmaktır. Ünlü sporcuların reklamlarda kullanılması birçok işletme ve organizasyon tarafından büyük ilgi görmektedir. Literatür incelendiğinde ünlü sporcuların geleneksel medya reklamlarında kullanımına ilişkin çok sayıda çalışma olmasına rağmen, ünlü sporcuların sosyal medya reklamlarında kullanılmasına ilişkin çok az çalışma olduğu görülmektedir. Son yillarda sosyal medya yeni ve popüler bir online pazarlama kanalı haline gelmiştir. Özellikle sosyal medya sitelerini kullanan tüketici sayısının her geçen gün artması, sosyal medyayı önemli bir reklam aracı haline getirmiştir. Öte yandan rol modeller tüketicilerin davranışların etkileyen önemli figürler olduğundan, pazarlamacılar için rol modellerin desteğinden yararlanmak gerçekten önemlidir. Çalışma Türkiye'nin Niğde ilinde 18-22 yaş aralığındaki 223 kişi ile gerçekleştirilmiştir. 223 katılımoıdan elde edilen verilerin analizinde yapısal eşitlik modeli kullanılmıştır. Sonuç olarak ünlü sporcuların rol model etkisiyle marka sadakati ve pozitif EWOM davranışı üzerinde pozitif bir ilişki olduğu bulunmuştur.

Anahtar Kelimeler: $\quad$ Sosyal Medya, Sporcu Ünlüler Z Kuşağı, Rol Model Etkisi 


\section{Introduction}

With the development of digital technology, using social media effectively has been an important marketing strategy for any business that wants to gain competitive advantage. Approximately 10,5 billion dollars was spent on social media ads by businesses in 2019. The number of brands that affect young people ( $\mathrm{Z}$ generation) by using sports celebrities in social media ads continues to increase day by day. Because sports celebrities are important role models for consumers and they are perceived as role models especially by young people.

The use of sports celebrities in advertising has been a popular strategy for traditional media. In the context of traditional media, celebrities who are known to be very effective in terms of ads are likely to show these effects in social media ads. When the literature is analyzed, although there are many studies on the use of sports celebrities in traditional media ads, it's seen that there are very few studies on the use of sports celebrities in social media ads.

In this respect, the study's very important to fill the gap in the literature. The purpose of the study is to reveal the relationship between the role model effect of the sports celebrities used in social media ads in the eyes of $Z$ generation and the brand loyalty.

\section{Social Media}

Social media does not have a generally accepted definition and there are many definitions. Therefore, there is no merger in a common definition (Koçyiğit, 2015). This can be explained by the fact that the concept of social media has a multi-faceted structure. When the literature is examined extensively, it is seen that the concept of social media is evaluated from different perspectives by many academicians from past to present. Thus, there are many defined expressions about social media: Richter and Koch (2007) define social media as online applications, platforms and media which aim to facilitate interactions, collaborations and the sharing of content. Evans (2008) defines social media as a platform that provides easy access to information and transforms people from content readers to content publishers. According to Sterne (2010), 
social media is a platform that enables everyone to communicate with everyone. Safko (2010) draws attention to the social aspect of social media and states that social media is the media used to socialize among people. Touchette et al. (2015) draws attention to the interactive structure of social media. There are two parties on social media: users and web publishers that provide space for the creation of collaborative information. Thus, social media is a communication method in which users can interact and participate jointly. Filo et al. (2015), on the other hand, define social media as new media technologies that facilitate the development and sharing of user-generated content between organizations and individuals by facilitating interaction and coformation.

\section{The Use of Sports Celebrities in Advertising}

The use of sports celebrities in advertising is of great interest to many businesses and organizations. Advertisers especially use athletes who are seen as superheroes by their target audience (Sukhdial et al., 2002). For years, advertisers have paid millions of dollars to sports celebrities to take part in their commercials. The use of sports celebrities in advertising is usually in the form of using a particular brand or wearing certain brands (Bush et al., 2004). Advertisers and their agencies are willing to pay huge salaries to sports celebrities who are liked and respected by target audiences and who will, it is hoped, favorably influence consumers' attitudes and behavior toward the endorsed brands (Shimp, 2003). Sports celebrities are effective in improving the image of the brands they promote and raising brand awareness (Keller, 1998). It is very important for consumers to create an emotional connection with the athlete. Thus, the positive features of the athlete can be transferred to the product and brand (Lear et al., 2009).

\section{The Use of Sports Celebrities in Social Media Advertising}

In recent years, social media has become a new and popular online marketing channel (Ding and Qiu, 2017). Especially, the increase in the number of consumers using social media sites day by day has made 
social media an important means of advertising (Jin and Puhua, 2014). While sports celebrities were trying to reach his fans through magazines and televisions in the past; today they use social media sites such as Facebook and Twitter to reach their fans (Cunningham and Bright, 2012). Thus, sports celebrities can reach a large number of people through social media. For example, the number of followers of the 10 most popular athletes on Twitter varies between 9.6 million and 38 million. However, on Instagram, these figures are much more than Twitter. For example, famous football player Cristiano Ronaldo has 177 million followers on Instagram. Famous basketball player Lebron James has 50 million followers.

Traditional methods such as writing letters to famous athletes, collecting their photos from newspapers or magazines, or subscribing to fan clubs limit consumers to contact with sports celebrities (Kassing and Sanderson, 2009). On the other hand, since social media provides consumers with direct access to famous athletes, it increases the interaction between sports celebrities and their fans. Li and Josh (2008) state that consumers may find the advertisements made by celebrities more believable and realistic than the advertisements in traditional media because social media offers a unique communication opportunity. Celebrities who tweet about brands and products on Twitter are often seen by their followers as fellow social media users, whether or not they are official brand endorsers (Schaefer, 2012). Because celebrities are also viewed as being more credible, trustworthy, attractive, and competent than ordinary twitter users. The advertisements of brands made by the celebrities through social media are perceived more credible and trustworthy, than the ads in the traditional media (Jin and Phua, 2014).

\section{Sports Celebrities as a Role Model}

In socializing process the individuals are influenced by culture, peers and role models. (Solomon, 2004). Role models are individuals who have qualities and behaviors usually liked and imitated by other people. Role models influence the individuals' decisions by communicating with them directly or indirectly (Bandura, 1977). An individual's intention to imitate the behavior of his/her role model depends on the individual's 
perception of similarity to the role model and the authority role model has on the individual (Berns, 1993). Role models can be any person from the people and the communities existing in every level of individuals' social life. These role models can be close people such as parents, relatives, friends and teachers, they can be also celebrities from politics, media or sports. It is really important for marketers to benefit from the support of role models, since the role models are important figures that influence the consumers'behaviours (Bush and Martin, 2000). Therefore, in product or brand advertisements, use of sports celebrities seen as role models can be a crucial method to influence the consumers' purchasing behavior.

Fame and success of sports celebrities inspire other people and have effect on them. Teenagers and young adults are more inclined to get influenced by sports celebrities compared to adults and elderly people. Especially teenagers tend to follow the footsteps of celebrities to fulfill some parts of their characters which they feel as incomplete (Weiss, 2004). For example, most teenagers wear and behave like the celebrities they admire. This enables them to increase their lower self confidence.

\section{Generation Z}

Generation $Z$ is the generation of people born between 1996 and 2010 (Read and Fromm, 2018). Generation $Z$ is the first generation who was born in a digital world. Thus, individuals from this generation are usually online, virtually they integrate and interact with their favorite brands (Bernstein, 2015). Forming interactions on social media web sites has become an important part of their social behaviors. The individuals from this generation use mostly social media to communicate and to interact more when compared to the ones from other generations. Furthermore they like commenting on and getting active feedbacks about the brands, products and services. They also pay attention to the views of other people on social media (Prakash and Yadav, 2017). Since the Generation $\mathrm{Z}$ has been in the beginning of developing their identities, they need external factors to shape their identities. Role models are one of the important external factors (Sladek and Grabinger, 2014). 


\section{Methodology}

This study was conducted with 223 people from ages 18-22 in Nigde, Turkey. The data survey is obtained from the questionnaire form by using convenience sample method in January-April of the year 2019. Structural equation model is used for the analysis of the data obtained from 223 participants. Famous athlete role model effect was assessed by using an adapted version of Rich (1997) role model scale. The role model scale included five items. The reliability coefficient of this scale was $\alpha=$ .936. Switching and complaining behavior and brand loyalty were assessed by using an adapted version of scales by Zeithaml et al (1996). Switching and complaining behavior scale included 4 items and the reliability coefficient of this scale was $\alpha=.821$. Brand loyalty behavior scale included 3 items and the reliability coefficient of this scale was $\alpha=$ 908. Positive EWOM behavior was assessed by using an adapted version of Bush et al. (2004). Positive EWOM scale included five items and the reliability coefficient of this scale was $\alpha=.882$. These scales utilized a 5-point strongly disagree to strongly agree continuum.

\section{Hypotheses}

Studies have found that sports celebrities used in traditional media advertisements such as TV, Newspaper and perceived as role models positively affect consumers' word of mouth marketing, brand loyalty and purchasing behavior (Bush et al. 2004; Makgosa, 2010). In this study, we examine the role model effect of sports celebrities in social media on Gen Z's brand loyalty, switching and complaining behavior and positive electronic word-of-mouth behavior (positive EWOM). The hypotheses are as follows:

H1: There is a positive relationship between the role model effect of sports celebrities and switching and complaining behavior of Gen Z.

$\mathrm{H} 2$ : There is a positive relationship between the role model effect of sports celebrities and brand loyalty of Gen Z.

H3: There is a positive relationship between the role model effect of sports celebrities and Positive EWOM behavior of Gen Z. 


\section{Results}

To test the structural model concerning the relationships among the study variables, a path analysis was performed using SPSS AMOS (Figure 1). The structural model was tested by confirmatory factor analysis before running to path analysis. The values found after the first analysis by confirmatory factor analysis were $\chi 2 / \mathrm{df}=3,696$; GFI $=0,916$; $\mathrm{CFI}=0,948$; RMSEA=0,071. According to these results, $\chi 2$ / df, GFI, RMSEA and CFI values show acceptable fit. However it was necessary to apply modification indices suggested by SPPS Amos to get good fit. In accordance with suggested modification indices, ewom2-ewom1, ewom3-ewom1; behavior2-behavior1, behavior4-behavior1, behavior4behavior3 and loyalty2-loyalty1 variables from the items predicting same factors were defined as error covariance. After modification, the results were $\chi 2 / \mathrm{df}=2,195, \mathrm{GFI}=0,951, \mathrm{CFI}=0,978, \mathrm{RMSEA}=0,047$. According to these results good fit was reached in all values. $P$ values are smaller than 0,01 . Since good fit values were provided in structural model as a result of confirmatory factor analysis, the research model suggested as structural model was tested by path analysis. The values found after path analysis were $\chi 2 / \mathrm{df}=3,696$; $\mathrm{GFI}=0,916$; $\mathrm{CFI}=0,948$; RMSEA $=0,071$. In examining the relationship between role model effect and switching and complaining behavior was found to have not a significantly positive relationship $(\beta=0,114, p>0,05)$. Thus, Hypothesis 1 was rejected. In examining the relationship between role model effect and brand loyalty was found to have a significantly positive relationship $(\beta=0,179, \mathrm{p}<0,03)$. Thus, Hypothesis 2 was supported. In examining the relationship between role model effect and Positive EWOM behavior was found to have a significantly positive relationship $(\beta=0,399, p<0,01)$. Thus, Hypothesis 3 was supported. 


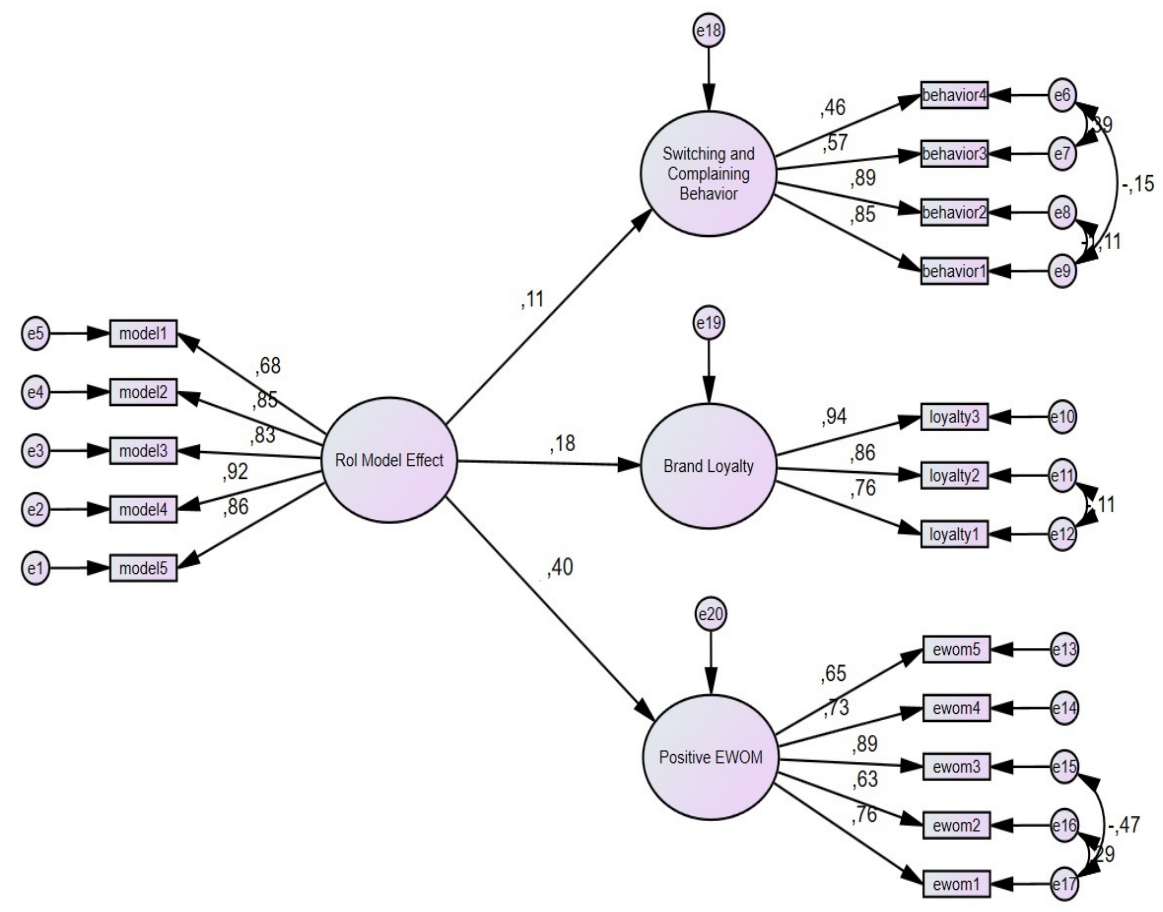

Figure 1. SPSS AMOS Result Screen

\section{Discussion and Implications}

Our findings from this study suggest several interesting implications for advertising researchers and practitioners. In this study, it was revealed that there is a positive relationship between the role model effect of sports celebrities and Gen Z's brand loyalty and positive EWOM behavior. There is a positive relationship between role model effect of sports celebrities and brand loyalty along with Positive EWOM behavior in Bush et al.'s study conducted with teenagers at the ages of 13-18 and in the study by Dix and Pougnet with young adults at the ages from 17 to 24 . The result that sports celebrities role model effect is significant for the gen $\mathrm{Z}$ consumers can be explained as they are more inclined to be 
influenced by celebrities than the older generations. Especially young people tend to follow the footsteps of celebrities to fulfill some lacking parts of their characters. Thus, in product and brand advertisements using famous athletes, perceived as role models, can be seen an important method to influence gen $\mathrm{Z}$ consumers'brand loyalty and Positive EWOM behavior.

\section{References}

Bandura, A. (1977). Social learning theory. Eaglewood Cliffs: Prentice Hall.

Berns, R. M. (1993). Child, family, community socialization and support. (3 ed.). USA: Harcourt Brace College.

Bernstein, R. (2015). Move over millennials e here comes Gen Z. Ad age. Web: http://adage.com/article/cmo-strategy/move-millennials-genz/296577/ 22 June 2019

Bush, A. J. and Martin, C. A. (2000). Do role models influence teenager's purchase intentions and behavior?. Journal of Consumer Marketing 17(5), 441-454.

Bush, A. J., Martin, C. A. and Bush, V. D. (2004). Sports celebrity influence on the behavioral intentions of generation Y. Journal of Advertising Research, 44(1), 108-117.

Cunningham, N. and Bright, L. (2012). The tweet is in your court: Measuring attitude towards athlete endorsements in social media. International Journal Of Integrated Marketing Communications, 4(2), 73-87.

Ding, Y. and Qiu, L. (2017). The impact of celebrity-following activities on endorsement effectiveness on microblogging platforms: A parasocial interaction perspective. Nankai Business Review International, 8(2), 158-173.

Evans, D. (2008). Social media marketing: An hour a day. Indianapolis: Wiley Publishing, Inc.

Filo, K., Lock, D. and Karg, A. (2015). Sport and social media research: A review. Sport Management Review, 18 (2), 166-181.

Jin S.A. and Phua J. (2014). Following celebrities' tweets about brands: The impact of twitterbased electronic word-of-mouth on consumers' source credibility perception, buying intention, and social identification with celebrities. Journal of Advertising, 43(2), 181-195. 
Kassing, J.W. and Sanderson, J. (2009), You're the Kind of guy that we all want for a drinking buddy: Expressions of parasocial interaction on Floydlandis.com. Western Journal of Communication, 73(2), 182-203.

Keller, K.L. (1998). Strategic brand management: Building, measuring, and managing brand equity. Upper Saddle River, NJ: Prentice-Hall.

Koçyiğit, M. (2015). Sosyal ă̆ pazarlaması, marka bă̆lllığı oluşturmada yeni bir pazarlama stratejisi. Konya: Eğitim Yayınevi.

Lear, K. E., Runyan, R. C. and Whitaker, W. H. (2009). Sports celebrity endorsements in retail products advertising. International Journal of Retail \& Distribution Management, 37(4), 308-321.

Li, C. and Josh B. (2008). Groundswell. Boston: Harvard Business Press.

Makgosa R. (2010). The influence of vicarious role models on purchase intentions of Botswana teenagers. Young Consumers, 11(4), 307-319.

Prakash, Y., G. and Rai, J. (2017). The generation $\mathrm{z}$ and their social media usage: A review and a research outline. Global Journal of Enterprise Information System, 9(2), 110.

Read, A. and Fromm J. (2018). Marketing to gen Z: The rules for reaching this vast-and very different-generation of influencers. USA: Amacom.

Rich, A. Gregory (1997) The sales manager as a role model: Effects on trust, job satisfaction and performance of salespeople. Journal of Academy of Marketing Science, 25, 319-328.

Richter, A. and Koch, M. (2007) Social Software-Status quo und Zukunft. Technischer Bericht, Nr.-01, Fakultatfür Informatik. Universitat der BundeswehrMünchen, Sweden.

Safko, L. (2010). The social media bible: Tactics, tools, and strategies for business success. (2nd edition ed). Hoboken, NJ: Wiley.

Schaefer, M. (2012). The Tao of Twitter: Changing your life and business 140 characters at a time. Columbus, OH: McGraw-Hill.

Shimp, T. (2003). Advertising and promotion: Supplemental aspects of integrated marketing communications. (6th ed). New York: Dryden Press, 292301.

Sladek, S. and Grabinger, A. (2014). Gen Z the first generation of the 21st century has arrived. Web: http://xyzuniversity.com/wp/content/uploads/2014/02/

GenZ_Final.pdf, 10 February 2019.

Solomon, M. R. (2004). Consumer behavior: Buying, having, and being. (6th eds). New York. Prentice Hall Inc. 
Sterne, J. (2010). Social media metrics: How to measure and optimize your marketing investment. New Jersey: John Wiley and Sons.

Sukhdial, A.S., Damon A. and Lynn K. (2002). Are You Old School? A Scale for Measuring Sports Fans' Old-School Orientation. Journal of Advertising Research 42, 4(2002), 71-81.

Touchette, B, Schanski., M. and Lee., S., L. (2015). Apparel brands 'use of Facebook: An exploratory content analysis of branded entertainment. Journal of Fashion Marketing and Management. 19(2), 107-119.

Weiss, T. (2004). Model behavior: Today's teens and the role models they choose. Web: www.teenagerstoday.com/resource/article/role/model.html 11 November 2018.

Zeithaml, V. A., Leonard L. B. and A. Parasuraman. (1996). The behavioral consequences of service quality. Journal of Marketing, 60(2), 31-46.

\section{Citation Information}

Mürütsoy, M. ve Toksarı, M. (2021). The role model effect of sports celebrites in social media on the behavioral intentions of generation Z. OPUS- International Journal of Society Studies, 18(Yönetim ve Organizasyon Özel Sayıs1), 1038-1049. DOI: 10.26466/opus.876057 